\title{
Author Correction: HIV-1 counteracts an innate restriction by amyloid precursor protein resulting in neurodegeneration
}

\author{
Qingqing Chai ${ }^{1}$, Vladimir Jovasevic ${ }^{1}$, Viacheslav Malikov ${ }^{1}$, Yosef Sabo ${ }^{2}$, Scott Morham ${ }^{3}$, Derek Walsh ${ }^{1} \&$ \\ Mojgan H. Naghavi ${ }^{1,2}$
}

Correction to: Nature Communications https://doi.org/10.1038/s41467-017-01795-8, published online 15 November 2017

The original version of this article contained an error in the Methods section 'Viruses and drugs'. The timing for drug treatment of CHME3 $4 \times 4$ or 293 T cells with $\gamma$-secretase inhibitor or BACE1 inhibitor was incorrectly given as ' 1 day prior to infection or transfection' and should have stated ' 4 or $6 \mathrm{~h}$ post transfection or infection, respectively'. This error is now corrected in both the PDF and HTML versions of the Article.

Published online: 05 June 2018

\begin{abstract}
(c) Open Access This article is licensed under a Creative Commons Attribution 4.0 International License, which permits use, sharing, adaptation, distribution and reproduction in any medium or format, as long as you give appropriate credit to the original author(s) and the source, provide a link to the Creative Commons license, and indicate if changes were made. The images or other third party material in this article are included in the article's Creative Commons license, unless indicated otherwise in a credit line to the material. If material is not included in the article's Creative Commons license and your intended use is not permitted by statutory regulation or exceeds the permitted use, you will need to obtain permission directly from the copyright holder. To view a copy of this license, visit http://creativecommons.org/licenses/by/4.0/.
\end{abstract}

(c) The Author(s) 2018

\footnotetext{
${ }^{1}$ Department of Microbiology-Immunology, Northwestern University Feinberg School of Medicine, Chicago, IL 60611, USA. ${ }^{2}$ Department of Biochemistry and Molecular Biophysics, Howard Hughes Medical Institute, Columbia University, New York, NY 10032, USA. ${ }^{3}$ MesaGen, LLC, South Salt Lake City, UT 84115 , USA. Correspondence and requests for materials should be addressed to M.H.N. (email: Mojgan.naghavi@northwestern.edu)
} 